[Agr. Biol. Chem., Vol. 25, No. 6, p. 466 472, 1961]

\title{
Microbiological Studies of Coli-aerogenes Bacteria
}

\author{
Part XVI. Enzymic Reduction of Glyoxylate to Glycollate by Coupling \\ with Dehydrogenases of Hexose Monophosphate Shunt Pathway* \\ By Tatsurokuro Tochikura, Tsutomu SAwa and Hideo Katagiri \\ Department of Agricultural Chemistry, Faculty of Agriculture, Kyoto University, Kyoto \\ Received January 16, 1961.
}

\begin{abstract}
The presence of glucose-6-phosphate markedly stimulated the anaerobic utilization of glyoxylate by either cell-free extracts or partially purified enzyme preparations of coli-aerogenes bacteria. The enzymic reduction of glyoxylate to glycollate was found to occur in the presence of TPN** with the following substrates; glucose-6-phosphate, glucose plus ATP, gluconate plus ATP, glucose-1-phosphate or malate. The data indicated that the reduction of glyoxylate to glycollate was coupled to the oxidation of glucose-6-phosphate via the hexose monophosphate shunt pathway. It was propounded that the operation of the hexose monophosphate oxidative pathway might be controlled by TPN-linked glyoxylic reductase, and the mechanisms of enzymic regulation in microbial respiration were also discussed.
\end{abstract}

\section{INTRODUCTION}

The first step of the hexose monophosphate shunt pathway is the formation of 6-phosphogluconate. This reaction is catalyzed by TPN-linked glucose-6-phosphate dehydrogenase. It has already been demonstrated ${ }^{1)}$ that in order to accumulate the oxidation product without adding stoichiometric quantities of TPN, reoxidation of TPNH is necessary by coupling with hydrogen-consuming enzyme systems such as malic enzyme acting on pyruvate plus carbon dioxide, isocitric dehydrogenase on $\alpha$-ketoglutarate plus carbon dioxide or glutamic dehydrogenase on $\alpha$-ketoglutarate plus $\mathrm{NH}_{4}^{+}$. Pentose-phosphate ${ }^{2)}$ has been known to be formed by a TPN-linked reaction

\footnotetext{
* Part XV, Bull. Inst. Chem. Res., Kyoto Univ., 13.

** The following abbreviations were used: TPN and DPN $=$ tri and diphosphopyridine nucleotides, respectively; $\mathrm{TPN}^{+}$and $\mathrm{TPNH}=$ oxidized and reduced triphosphopyridine nucleotides, respectively; $\mathrm{ATP}=$ adenosine triphosphate; $\mathrm{ADP}=$ adedosine diphosphate

1) J.B. Sumner and K. Myrbäck, "The Enzymes", Academic Press Inc., 2, 929 (1952).

2) B.L. Horecker and P.Z. Smyrniotis, J. Biol. Chem., 193., 371 (1951).
}

between lactic dehydrogenase and 6-phosphogluconate dehydrogenase. In the present paper, the authors' attention has been directed towards another TPNH-oxidizing reaction, i.e., TPN-linked glyoxylic acid reductase of coli-aerogenes bacteria. In the previous papers, the authors have studied the mode of degradation of tricarboxylic acids by microorganisms including coli-aerogenes bacteria $^{3 \sim 13)}$ and Saccharomyces species ${ }^{11)}$, and it has been indicated that isocitritase-glyoxylic acid reductase system $7,9.11,12.14)$ may play a very important role in microbial carbon-

\footnotetext{
3) H. Katagiri and T. Tochikura, This Journal, 22, 143 (1953).

4) H. Katagiri and T. Tochikura, ibid., 23, 475 (1959).

5) H. Katagiri and T. Tochikura, ibid., 23, 482 (1959)

6) H. Katagiri and T. Tochikura, ibid., 23, 489 (1959)

7) H. Katagiri and T. Tochikura, ibid., 23, 558 (1959).

8) H. Katagiri and T. Tochikura, Bull. Inst. Chem. Res., Kyoto Univ., 38, 94 (1960).

9) H. Katagiri and T. Tochikura, This Journal 24, 351 (1960).

10) H. Katagiri and T. Tochikura, ibid., 24, 357 (1960).

11) H. Katagiri and T. Tochikura, Amino Acids, 2, 138 (1960).

12) H. Katagiri and T. Tochikura, Bull. Inst. Chem. Res., Kyoto Univ., 38, 379 (1960).

13) H. Katagiri and T. Tochikura, ibid., 38, 386 (1960)

14) H. Katagiri, T. Tochikura and H. Matsuoka, ibid., 38, 406 $(1960)$.
} 
metabolisms. Further investigations have strongly suggested that the combined reaction of glyoxylic reductase-glycollic oxidase (dehydrogenase) may function as a hydrogen carrier system in the respiration of microorganisms ${ }^{7,10,14,15)}$. The function of glyoxylate $\rightleftharpoons$ glycollate system in higher plants has already been reported by several workers ${ }^{16 \sim 20)}$.

\section{EXPERIMENTAL AND RESULTS}

\section{Methods.}

Bacterial strains employed in this paper were Escherichia coli (strain G-2) and Aerobacter aerogenes (strain B-2). All the chemicals used were the commercial products. Ketonic acids were identified by paper-partition chromatography of the 2,4-dinitrophenylhydrazones and determined by a modification of methods of Carvallini et al ${ }^{21}$. Glycollic acid was estimated by the method of Dagley and Rodgers22). Protein was determined according to the method of Lowry et al ${ }^{23)}$.

Enzyme Preparation. The bacteria were grown on a shaker at $30^{\circ} \mathrm{C}$ for 20 hours with the following media: (1) glucose-medium ( $\mathrm{pH} 7.0 \sim 7.2$ ) containing $2 \%$ glucose, $1 \%$ each chrysalis extract and peptone, $0.2 \% \mathrm{NaCl}, 0.1 \% \quad \mathrm{KH}_{2} \mathrm{PO}_{4}$ and $0.3 \%\left(\mathrm{NH}_{4}\right)_{2} \mathrm{SO}_{4}$ and $1 \% \mathrm{CaCO}_{3}$; (2) gluconate-medium ( $\left.\mathrm{pH} 7.2\right)$ containing $1.5 \%$ each Na-gluconate and glucose, $1 \%$ each chrysalis extract and peptone, $0.2 \% \mathrm{NaCl}, 0.1 \%$ $\mathrm{KH}_{2} \mathrm{PO}_{4}$ and $0.3 \% \quad\left(\mathrm{NH}_{4}\right)_{2} \mathrm{SO}_{4}$ After cultivation, bacterial cells were harvested by centrifugation, washed with distilled water, and disintegrated by treatment with a $10 \mathrm{kc}$. Raytheon oscillator in the similar way as described previously ${ }^{5)}$. After removal of inact cells and cell debris, cell-free extracts were dialyzed against distilled water at $5^{\circ} \mathrm{C}$ for $20 \sim$ 40 hours. An ammonium sulfate fraction of 0.3 to 0.6 saturation from the cell-free extracts was prepared

\footnotetext{
15) T. Tochikura, A. Kamimura and H. Katagiri, Bull. Inst. Chem. Res. Kyoto Univ., 39, 57 (1961).

16) C.O. Clagett, N.E. Tolbert and R.H. Burris, J. Biol. Chem., 178, 977 (1949).

17) N.E. Tolbert, C.O. Clagett and R.H. Burris, J. Biol. Chems, 181, 905 (1949)

18) I. Zelitch and S. Ochoa, J. Biol. Chem., 201, 707 (1953).

19) I. Zelitch, ibid., 201, 719 (1953).

20) I. Zelitch, ibid., 216, 553 (1955)

21) D. Cavallini, N. Frontali and G. Toschi, Nature, 163, 568 ; 164, 792 (1949).

22) S. Dagley and A. Rodgers, Biochim. Biophys. Acta, 12, 591 (1953).

23) O.H. Lowry, N.J. Rosenbrough, A.L. Forr and R.T. Randall, J. Biol. Chem., 193, 265 (1951).
}

according to the method mentioned in the previous papers ${ }^{5)}$. Further treatment was carried out with the preparation of glucose-grown $A$. aerogenes. Alumina $\mathrm{C}_{\gamma}$ gel $(22 \mathrm{ml})$ containing $32 \mathrm{mg}$ of dry weight per $\mathrm{ml}$ was added to $30 \mathrm{ml}$ ( $23 \mathrm{mg}$ protein per $\mathrm{ml}$ ) of the ammonium sulfate fraction of $0.3 \sim 0.6$ saturation. After standing for 20 minutes at $3^{\circ} \mathrm{C}$, the gel suspension was centrifuged and the precipitate discarded. By this procedure, specific activity of TPN-glyoxylic reductase in the supernatant solution (enzyme Es) could be increased by 4 times of the cell-free extracts. To the supernatant solution (Es) was added solid ammonium sulfate to give 0.45 saturation. The suspension was stirred for 15 minutes at $3^{\circ} \mathrm{C}$ and then centrifuged. The precipitate (enzyme Ep) was dissolved in $0.1 \mathrm{M}$ phosphate buffer, $\mathrm{pH} 7.4$ and dialyzed against distilled water at $5^{\circ} \mathrm{C}$ for 20 hours. Es and Ep enzyme preparations were found to contain both glucose-6-phosphate dehydrogenase and glyoxylic reductase.

\section{Coupled Reaction between Glyoxylic Reductase and} Glucose-6-phosphate Dehydrogenase.

Tables I and II show the effect of addition of glucose-6-phosphate on the consumption of glyoxylate

TABLE I. EFFeCt OF AdDition OF GLuCOSE-6PHOSPHATE ON ANAEROBIC UTILIZATION OF GLYOXYLATE BY CELL EXTRACT OF GLUCOSE-GROWN $A$. aerogenes

Glucose-6-phosphate added ( $\mu$ moles) $\quad \begin{array}{llll}0 & 15.0 & 30.0\end{array}$ $\begin{array}{lllll}\text { Glyoxylate consumed ( } \mu \text { moles) } & 3.8 & 12.1 & 15.0\end{array}$

Reaction mixture contained $100 \mu$ moles phosphate buffer, $\mathrm{pH}$ 7.4, $5 \mu$ moles $\mathrm{MgSO}_{4}, 15 \mu$ moles Na-glyoxylate, $0.1 \mu$ mole TPN, the dialyzed cell-free extract $(9 \mathrm{mg}$ as protein) of glucose-grown $A$. aerogenes and the indicated amounts of glucose-6-phosphate (potassium salt); total volume, $3.0 \mathrm{ml}$; 90 minutes' incubation at $37^{\circ} \mathrm{C}$ anaerobically, Thunberg tube in vacuo.

by the dialyzed cell-free extract of a glucose-grown $A$. aerogenes. It has been observed that glucose-6-phosphate stimulates the anaerobic degradation of glyoxylate when the incubation is carried out in the presence of TPN. Analytical results showed that glyoxylate was converted to glycollate in the presence of both gluocse-6-phosphate and TPN. Increasing the amount of glucose-6-phosphate resulted in both the rapid disappearance of glyoxylate and the remarkable formation of glycollate, as is shown in Table II. This reaction showed high specificity toward TPN. The reduction of glyoxylate to glycollate must be coupled with an oxidative reaction. The results of experi- 
TABLE II. EFFECT OF ADDITION OF GLuCOSE-6PHOSPHATE AND TPN ON ANAEROBIC UTILIZATION OF GLYOXLATE AND FORMATION OF Glycollate by Cell Extract of GLUCOSE-GROWN $A$. aerogenes.

$$
\begin{aligned}
& \text { Glucose-6-phosphate added } \\
& \text { ( } \mu \text { moles) } \\
& \text { TPN added }(0.1 \mu \text { mole })++\quad+\quad+ \\
& \text { Glyoxylate consumed } \\
& \text { ( } \mu \text { moles) } \\
& \begin{array}{lllll}
7.2 & 10.1 & 12.5 & 7.5 & 15.0
\end{array}
\end{aligned}
$$

ments mentioned above indicate that the reaction involved is the glucose-6-phosphate oxidative pathway. Tables I and II also imply that some portion of glyoxylate may be metabolized by a TPN-independent

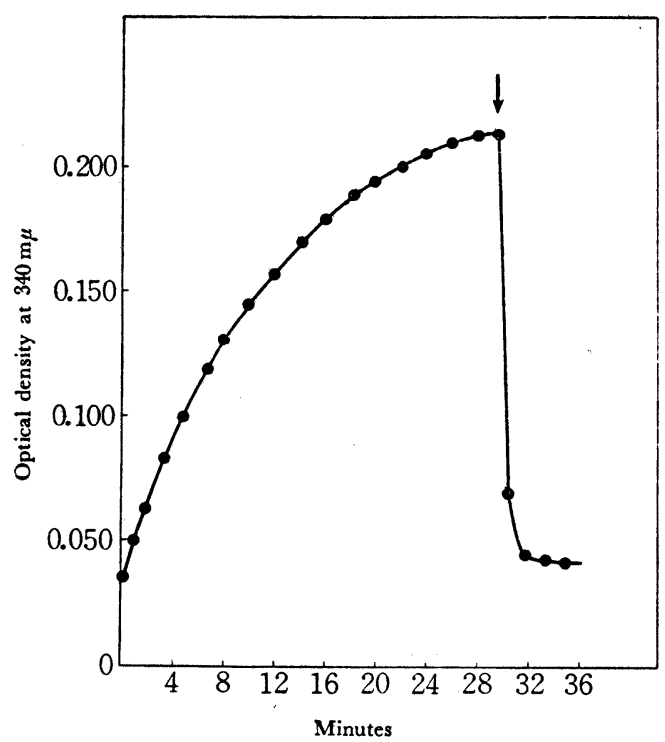

FIG. I. Enzymic Reduction of $\mathrm{TPN}^{+}$in Presence of Glucose-6-phosphate and Enzymic Reoxidation of TPNH in Presence of Glyoxylate.

Reaction mixture contained $170 \mu$ moles phosphate buffer, $\mathrm{pH} 7.4$, $5 \mu$ moles $\mathrm{MgSO}_{4}, 7.5 \mu$ moles glucose-6-phosphate, approximately $0.13 \mu$ mole TPN and $760 \mu \mathrm{g}$ (as protein) of partially purified enzyme preparation (Ep) from glucose-grown $\boldsymbol{A}$. aerogenes. At the time indicated by the arrow, $12 \mu$ moles of Na-glyoxylate were added. The final volume after addition was $3.0 \mathrm{ml}$. The reduction of or reoxidation of TPN was determined at room temperature at $340 \mathrm{~m} \mu$ spectrophotometrically with a Shimadzu model QB spectrophotometer, $1 \mathrm{~cm}$. light path. system of the bacteria. Subsequently, the participation of glucose-6-phosphate dehydrogenase in the utilization of glyoxylate was demonstrated spectrophotometrically with the partially purified enzyme preparations (Ep) of $A$. aerogenes. The results are shown in Fig. 1. The reoxidation of TPN occurred at an exceedingly high rate in the presence of glyoxylate. It has now been established that the dehydrogenation of glucose-6-phosphate is coupled to the reduction of glyoxylate to glycollate, according to the following reactions:

$$
\begin{array}{r}
\begin{array}{r}
\text { Glucose-6-phosphate }+\mathrm{TPN}^{+} \longrightarrow \\
\text { 6-phosphogluconate }+\mathrm{TPNH}+\mathrm{H}^{+} \\
\text {(glucose-6-phosphate dehydrogenase) }
\end{array} \\
\begin{array}{r}
\text { Glyoxylate }+\mathrm{TPNH}+\mathrm{H}^{+} \longrightarrow \text { glycollate }+\mathrm{TPN}{ }^{+} \\
\text {(glyoxylic reductase) }
\end{array} \\
\begin{array}{r}
\text { Sum Glucose-6-phosphate + glyoxylate } \longrightarrow \\
\text { 6-phosphogluconate }+ \text { glycollate }
\end{array}
\end{array}
$$

This finding has strongly suggested that microbial glyoxylic reductase may function as one member of TPNH-oxidizing systems in the hexose monophosphate shunt pathway.

\section{Enzymic Reduction of Glyoxylate in Presence of} Several TPNH-Generating Systems.

Tables III and IV show the effect of several TPNH -generating systems on the anaerobic utilization of glyoxylate by the dialyzed cell-free extracts of $A$. aerogenes. The reduction of glyoxylate to glycollate was demonstrated with the following substrates: glucose plus ATP, gluconate plus ATP, glucose-1-phosphate and glucose-6-phosphate. Both mannitol plus ATP and fructose plus ATP appear to be inactive in the test system. Similar effects of glucose-6-phosphate and gluconate plus ATP have been observed with the dialyzed cell-free extract of glucose-grown $E$. coli, as is shown in Table $V$. In the experiments carried out with either glucose or gluconate, the formation of glycollate was extremely decreased unless ATP was present. However, it has been found that when either glucose-6-phosphate or glucose-1-phosphate is used, ATP inhibits the utilization of glyoxylate.

. It may be indicated that the cell extracts used here contain the following enzymes: hexokinase, gluconokinase, phosphoglucomutase, glucose-6-phosphate dehydrogenase, 6-phosphogluconic dehydrogenase and glyoxylic reductase. Thus, the reduction of glyoxylate to glycollate may proceed according to the reactions shown in next page. 
Table III. Effect of Addition of Hexose, Hexose Phosphate, Gluconate, and ATP on Anaerobic Utilization of GlyoXylate By Cell-Free Extracts From Cells of Either GluCOSE OR GLUCONATE-GROWN $A$. aerogenes

Cell-free ext. (11 mg protein) of glucose-grown
A. aerogenes

TPNH-generating substrates ( $\mu$ moles)

None

Glucose 50.0 plus ATP 10.0

Mannitol 50.0 plus ATP 10.0

Glucose-1-phosphate 50.0

Glyoxy
consum
$(\mu \mathrm{mol})$
4.0
8.7
4.0
16.3
5.3
4.2
5.2
18.2
12.1
3.9

Glucose-1-phosphate 50.0 plus ATP 10.0

Fructose 50.0 plus ATP 10.0

Na-gluconate 50.0

Na-gluconate 50.0 plus ATP 10.0

Glucose-6-phosphate 20.0

$3.9 \quad 3.0$

Glycollate
formed
$(\mu$ moles $)$
0

5.7

0

15.2

2.0

17.7

8.1

3.0
Cell-free ext. (13 mg protein) of gluconate plus glucose-grown A. aerogenes

$\begin{array}{cc}\begin{array}{c}\text { Glyoxylate } \\ \text { consumed } \\ (\mu \text { moles })\end{array} & \begin{array}{r}\text { Glycollate } \\ \text { formed } \\ (\mu \text { moles })\end{array} \\ 8.0 & 0 \\ 11.6 & 7.2 \\ 8.5 & 0 \\ 13.3 & 5.8 \\ 9.2 & \\ 8.8 & \\ 9.2 & 0 \\ 20.0 & 18.8 \\ 14.3 & 7.0 \\ 11.2 & 4.5\end{array}$

11.2

4.5

Reaction mixture contained $250 \mu$ moles phosphate buffer, pH 7.2, $5 \mu$ moles $\mathrm{MgSO}_{4}, 0.09 \mu$ mole TPN, $20 \mu$ moles Na-glyoxylate, indicated amounts of additions and dialyzed cell-free extracts of $A$. aerogenes; total volume, $3.0 \mathrm{ml} ; 90$ minutes' incubation at $37^{\circ} \mathrm{C}$; anaerobically, Thunberg tube in vacuo.

It should be noted here that gluconokinase is present in glucose-grown cells of coli-aerogenes. This

Glucose + ATP $\longrightarrow$ glucose-6-phosphate + ADP (hexokinase)

Glucose-1-phosphate $\leftrightharpoons$ glucose-6-phosphate (phosphoglucomutase)

Gluconate + ATP $\longrightarrow 6$-phosphogluconate + ADP (gluconokinase)

Glucose-6-phosphate+TPN

6-phosphogluconate $+\mathrm{TPNH}+\mathrm{H}^{+}$ (glucose-6-phosphate dehydrogenase)

6-Phosphogluconate $+\mathrm{TPN}^{+}$

pentose-phosphate $+\mathrm{CO}_{2}+\mathrm{TPNH}+\mathrm{H}^{+}$ (6-phosphogluconate dehydrogenase)

Glyoxylate $+\mathrm{TPNH}+\mathrm{H}^{+} \longrightarrow$ glycollate $+\mathrm{TPN}^{+}$ (glyoxylate reductase)
TABle IV. EFFect of AdDition of Glucose AND ATP ON REDUCTION OF GLYOXYLATE BY CELL-FREE EXTRACT FROM GLUCOSEGROWN CELLS OF $A$. aerogenes

Additions

Glyoxylate

Glucose

ATP

$\begin{array}{llll}\text { Glycollate formed ( } \mu \text { moles) } & 11.9 & 3.8 & \text { Trace }\end{array}$

Complete system contained $250 \mu$ moles phosphate buffer, $\mathrm{pH} 7.2$, $5 \mu$ moles MgSO, $10 \mu$ moles ATP, $50 \mu$ moles glucose, $25 \mu$ moles $\mathrm{Na}$ glyoxylate, $0.1 \mu$ mole TPN and the dialyzed cell-free extract $(18 \mathrm{mg}$ as protein) of glucose-grown $A$. aerogenes; total volume, $3.0 \mathrm{ml}$; 180 minutes' incubation at $37^{\circ} \mathrm{C}$; anaerobically, Thunberg tube in vacuo.

TABle V. EFFect of Addition of Glucose-6-Phosphate, GluConate and ATP on Reduction of Glyoxylate by Cell Extract of GluCose-Grown $E$. coli

Glucose-6-phosphate added ( $\mu$ moles)

Gluconate added ( $\mu$ moles)

ATP added ( $\mu$ moles)

Glyoxylate consumed ( $\mu$ moles)

Glycollate formed ( $\mu$ mole)

$\begin{array}{cc}0 & 20.0 \\ 0 & 0 \\ 0 & 0 \\ 6.8 & 19.0 \\ \text { Trace } & 17.9\end{array}$

$$
0
$$

0

10.0

6.0

1.5
0

50.0

10.0

11.6

8.5
0

13.9

Reaction mixture contained $250 \mu$ moles phosphate buffer, pH 7.2, $5 \mu$ moles MgSO $430 \mu$ moles Na-glyoxylate, $0.12 \mu$ mole TPN, indicated amounts of glucose-6-phosphate, ATP and Na-gluconate, and the dialyzed cell-free extract (19 mg as protein) of glucose-grown $E$. coli; total volume, $3.0 \mathrm{ml} ; 2.5$ hours' incubation at $37^{\circ} \mathrm{C}$; anaerobically, Thunberg tube in vacuo. 
may imply that some portion of glucose is oxidized to gluconate, prior to phosphorylation.

\section{Effect of Malate.}

As is shown in Table VI, the addition of L-malate markedly stimulates the rate of anaerobic consumption of glyoxylate by the cell-free preparation of gluconategrown $A$. aerogenes when incubations are carried out in the presence of TPN. The remarkable formation of pyruvate was also observed in the presence of either TPN or DPN. There was less effect with DPN. Fig. 2 shows the spectrophotometric observation on the dismutation between the oxidation of malate and the reduction of glyoxylate, in the presence of TPN.

TABle VI. EFFeCt of AdDition OF Pyridine NUCLEOTIDES ON COUPLED REACTION BETWEEN GLYOXYLATE AND MALATE

$\begin{array}{cccc}\begin{array}{c}\text { Pyridine nucleotides } \\ \text { added } \\ (\mu \text { mole) }\end{array} & \begin{array}{c}\text { Glyoxylate } \\ \text { consumed } \\ \text { ( } \mu \text { moles) }\end{array} & \begin{array}{c}\text { Pyruvate } \\ \text { formed } \\ (\mu \text { moles })\end{array} \\ & 0 & 4.6 & 0 \\ \text { TPN } & 0.07 & 9.6 & 4.7 \\ \text { TPN } & 0.13 & 13.1 & 8.2 \\ \text { DPN } & 0.28 & 8.8 & 6.8\end{array}$

Reaction mixture contained $300 \mu$ moles phosphate buffer, $\mathrm{pH} 7.4$ $5 \mu$ moles $\mathrm{MgSO}_{4}, 17 \mu$ moles Na-glyoxylate, $100 \mu$ moles Na-L-malate, indicated amounts of pyridine nucleotides, and the dialyzed cellfree extract $(20 \mathrm{mg}$ as protein) of $\boldsymbol{A}$. aerogenes grown on gluconate; total volume, $3.0 \mathrm{ml} ; 120$ minutes' incubation at $37^{\circ} \mathrm{C}$; anaerobically, Thunberg tube in vacuo.

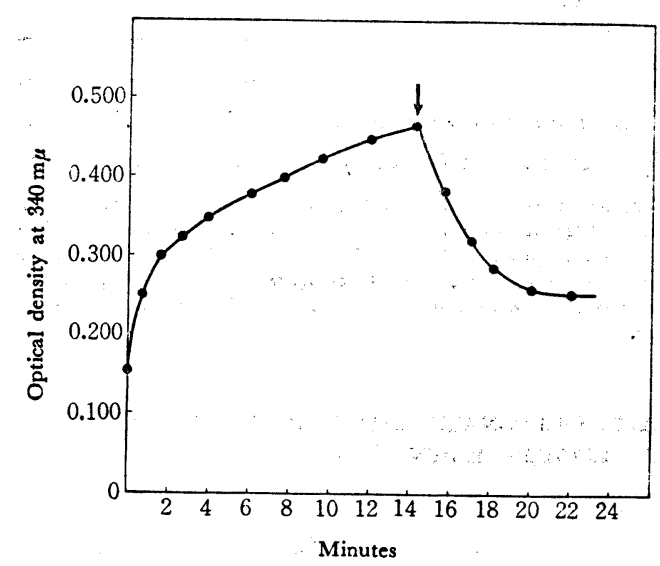

FIG. 2. Enzymic Reduction of $\mathrm{TPN}^{+}$by L-Malate and Enzymic Reoxidation of TPNH by Glyoxylate.

Reaction mixture jcontained $170 \mu$ moles phosphate buffer, $\mathrm{pH} 7.4$, $5 \mu$ moles $\mathrm{MgSO}_{4}, 10 \mu$ moles Na-L-malate, approximately $0.23 \mu$ mole TPN and the dialyzed cell-free extract $(1.4 \mathrm{mg}$ as protein) of gluconate-grown $A$. aerogenes. At the time indicated by the arrow, $7 \mu$ moles of Na-glyoxylate were added; final volume, $3.0 \mathrm{ml}$.
Thus, the results of experiments are explained according to the following equations:

$$
\text { Malate }+\mathrm{TPN}+\longrightarrow \text { pyruvate }+\mathrm{CO}_{2}+\mathrm{TPNH}+\mathrm{H}^{+}
$$

Glyoxylate $+\mathrm{TPNH}+\mathrm{H}^{+} \longrightarrow$ glycollate $+\mathrm{TPN}^{+}$

Sum Malate + glyoxylate $\longrightarrow$ pyruvate + glycollate $+\mathrm{CO}_{2}$

\section{DISCUSSION}

Evidence for the operation of regulative mechanism on the level of enzymes has been presented in this paper.

Glyoxylic acid is known to be produced from $\mathrm{C}_{6}$-tricarboxylic acids ${ }^{24)}$ by the action of isocitritase. On the other hand, glyoxylate has been found to be reduced to glycollate by a TPN-linked enzyme of microorganisms ${ }^{7,9,11}$. Both isocitritase (glyoxylate-generating enzyme) and glyoxylic reductase (glycollategenerating enzyme) have been demonstrated in the cells obtained from various growthmedia containing glucose, acetate, citrate or gluconate as the source of carbon..$^{3 \sim 9,11 \sim 15)}$.

The results of experiments reported here have indicated that the reduction of glyoxylate to glycollate is coupled to the oxidation of glucose-6-phosphate via the hexose monophosphate shunt pathway. In the living cells of microorganisms, therefore, it has been suggested that the operation of hexose monophosphate shunt pathway which requires the presence of oxidized TPN, may be controlled by TPN-linked glyoxylic reductase. This implies that glyoxylic reductase may function as an accelerator of the metabolic shift from the Embden-Meyerhof-Parnas pathway to the hexose monophosphate pathway (Fig. 3).

As already mentioned in the previous papers ${ }^{7,9}$ ) the formation of $\alpha$-ketoglutarate from isocitrate occurs by a TPN-coupled reaction between isocitric dehydrogenase and glyoxylic reductase. Further investigations ${ }^{11,12)}$ have indicated the possibility of a competition between the formation of gluta-

24) J.J.R. Campbell, R.A. Smith and B.A. Eagles, Biochim. et. Biophys. Acta, 11, 594 (1953). 


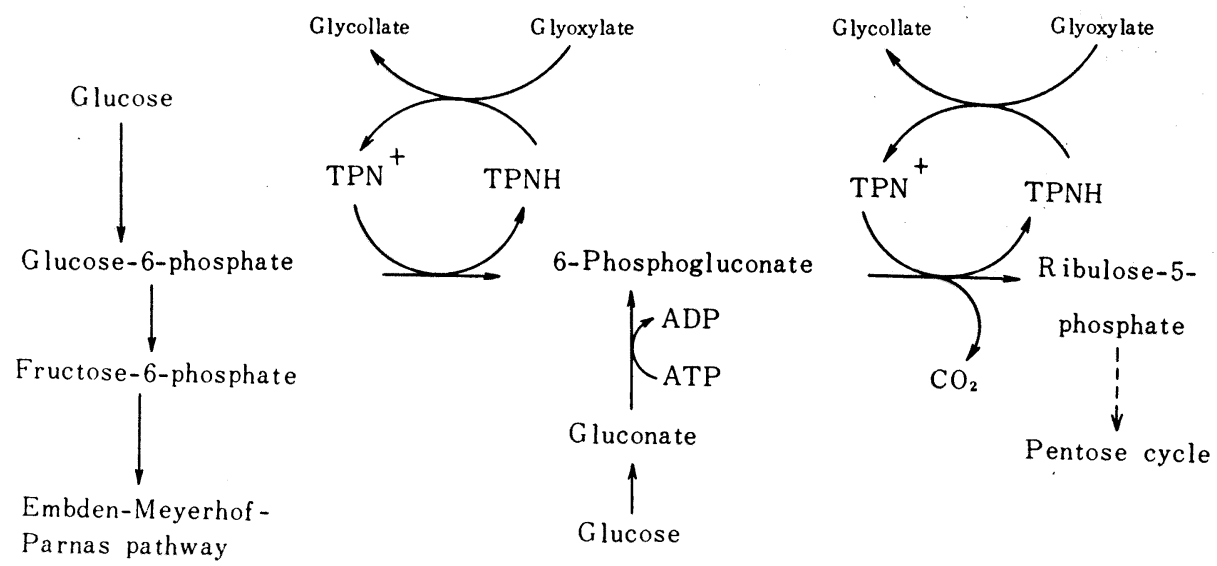

FIG. 3. Function of Glyoxylate Reductase in Microbial Metabolism of Glucose.

mate and carbon dioxide by the isocitric de- isocitritase-isocitric dehydrogenase-glyoxylic hydrogenase-glutamic dehydrogenase system, reductase system. Based on the experimental and the formation of glycollate, $\alpha$-ketogluta- results mentioned in the present paper, it has rate, succinate and carbon dioxide by the now been propounded that the isocitritase-

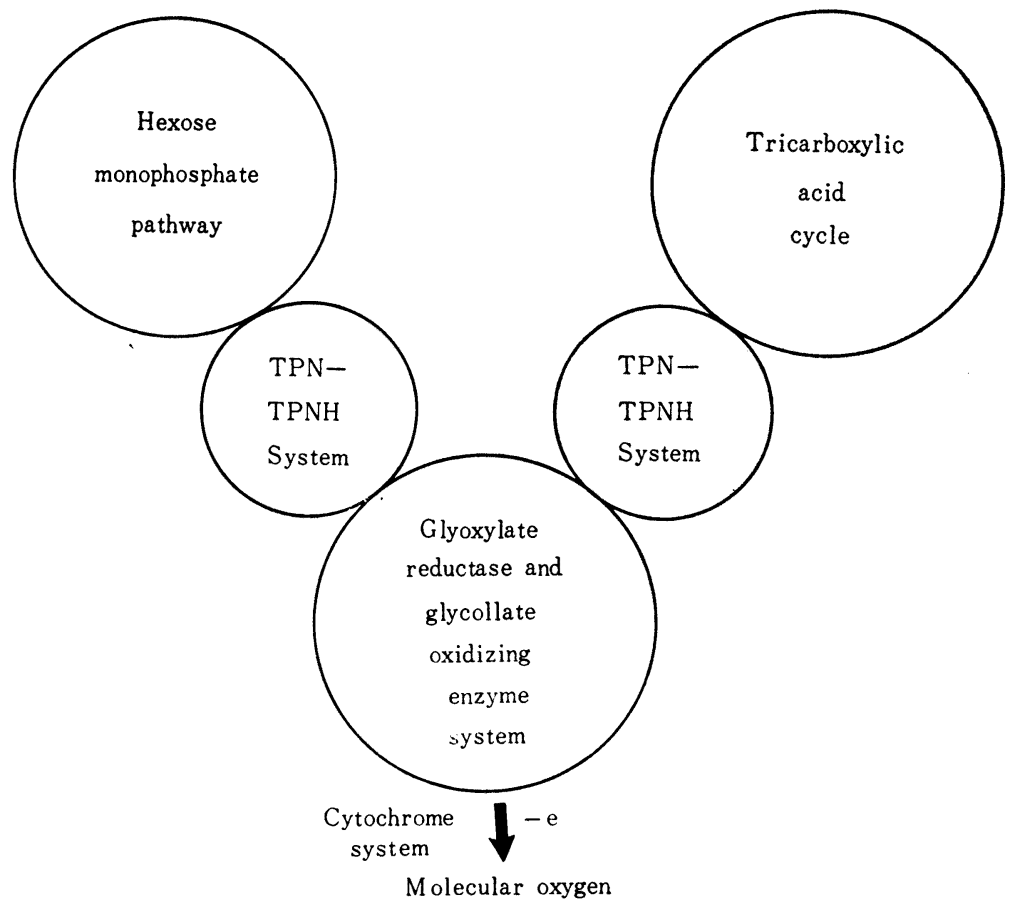

FiG. 4. Function of Glyoxylate Reductase and Glycollate Oxidizing Enzyme System in Microbial Respiration. 
glyoxylic reductase system may serve as a regulator between the hexose monophosphate shunt pathway and the tricarboxylic acid cycle. Glycollate is oxidized to glyoxylate by the microbial flavoprotein (with FMN as prosthetic group and independently, of TPN or DPN) ${ }^{7,10,14,15)}$. Consequently, the micro- bial glyoxylate reductase and glycollate oxidizing enzyme system may carry out hydrogen (electron) transportation between the hexose monophosphate pathway and molecular oxygen, and between the tricarboxylic acid cycle and molecular oxygen, accordidng to the simplified scheme shown in Fig. 4. 